\title{
Model Of Correlation Of Work Motivation And Organizational Commitment Through Workplace Spirituality And Servant Leadership
}

\author{
Lia Amalial, Basman Nurafian2 \\ 1,2Management, Faculty of Economics and Business, Esa Unggul University, Jakarta 11510 \\ lia.amalia@esaunggul.ac.id
}

This study aims to determine the effect of Servant Leadership on Organizational Commitment through Workplace Spirituality and Work Motivation. The independent variable consists of Servant Leadership, the dependent variable is Organizational Commitment and the intervening variables are Workplace Spirituality and Work Motivation. This research was conducted on millennial-generation employees who worked for more than one year within Tangerang area. The samples used were 160 respondents with purposive sampling technique. This type of research is causal associative in nature and the method used in this research is Path Analysis. The results of this study indicate that Servant Leadership has positive and significant effect on Workplace Spirituality and Work Motivation. Workplace Spirituality and Work Motivation have a positive and significant effect on Organizational Commitment, while Servant Leadership does not have a positive and significant effect on Organizational Commitment. Workplace Spirituality and Work Motivation have successfully become the Intervening variables for Servant Leadership.

Keywords: Servant Leadership, Workplace Spirituality, Work Motivation, Organization Commitment

OPEN ACCESS ISSN 2528-4649 (online) ISSN 2338-4409 (print)

Reviewedby: Qristin Violinda S.Psi,MM,Ph.D

${ }^{*}$ Correspondence: Lia Amalia lia.amalia@esaunggul.ac.id Received: December 21, 2020 Accepted: March 20, 2021 diterima Published: March 31 , 2021

JBMP: Jurnal Bisnis, Manajemen dan Perbankan. Vol: $7 /$ No. 1 doi: 10.21070/jbmp.v7i1.1161 


\section{INTRODUCTION}

The number of changes currently occurring makes human resources have to adjust to changes, one of which is in the workplace. Changes that occur in companies can be seen from human resources perspective, where the number of generations in an organization were dominated by different individuals, especially the millennial generation. The millennial generation at the workplace is an important factor today because $33.25 \%$ of the job positions are occupied by the millennial generation at the workplace. These changes will continue to occur and the company must be prepared to face this so that the company can continue their business activities well. Therefore it is important to recognize the characteristics of the millennial generation and pay attention as well as get to know them better so that the millennial generation will be able to hold more organizational commitment.

Motivation can also be said to be a series of efforts to provide certain conditions, so that someone wants and intends to do something, and if one does not like to provide the same, then he will try to eliminate or avoid that feeling of dislike. From this definition, it can be said that someone who has work motivation will maximize his efforts to complete the work one has, even though in the process of completing the job there are obstacles or feelings of dislike for the task or job given, but there will be a sense of effort to eliminate the dislike of one's job. This also relates to the feelings of individuals who feel that they are the part of the company where they work or so-called workplace spirituality.

Workplace spirituality is further explained by Robbins (2008) that, "spirituality in the workplace realizes that humans have an inner life that grows and is cultivated by meaningful work that takes place in a community context. Organizations that support spiritual culture recognize that humans have a mind and soul, seek meaning and purpose in their work, desire to relate to other people, and be part of a community." In other words, workplace spirituality is describing humans with certain minds and souls who have found meaning and purpose in the work they have. This also means considering themselves part of the company. This assumption illustrates that in a person there is the emergence of a feeling of comfort in doing certain work. Another factor is the feeling of getting good handling such as concern and welfare of the company's structural or so-called servant leadership.

According to Darmawan (2013), organizational commitment is the desire of employees to maintain their membership in the organization and are willing to make high efforts for achieving organizational goals. Organizational commitment can also be interpreted as a form of employee trust in the company and he, therefore, can work for the company by himself without facing any meaningful coercion. Organizational commitment cannot present itself in a person. To create organizational commitment requires influence from the company and the environment within the company. Several companies are currently dominated by human resources with the category of millennial generation. Based on the graph results in the Deloitte Indonesia Perspective article:
[Figure 1 about here.]

[Figure 2 about here.]

The results of the graph above explain that in the world of work, the millennial generation has a free character, this can be seen from the graph above that a pleasant office atmosphere is ranked second of $68 \%$ after work appreciation of $83 \%$. The millennial generation does not like binding regulations, this can also be seen from the graph above that flexibility in the workplace shows a value of $61 \%$ and flexible communication of $60 \%$. Based on these characteristics, it can be seen that not many millennial generations have an organizational commitment in themselves. This organizational commitment can be influenced by several factors such as work motivation, workplace spirituality, and servant leadership.

\section{METHOD (FOR RESEARCH ARTICLE)}

Research design is a guideline or procedure and technique in research planning that is useful as a guide for building strategies that produce the research model as cited by Sujarweni (2015). According to the Kamus Besar Bahasa Indonesia (KBBI) the fifth edition, causal words have the character of causing an event or one cause may trigger another cause/causing each other (relationship). So it can be interpreted that causal research has the main objective of proving a causal relationship or a relationship that affects and is influenced by the variables as studied by Istijanto (2009). Likewise, Sugiyono (2012) states that a causal relationship is a relationship that is causal in nature. The research design of this research is causality research. Researchers will try to determine the variables that affect or cause changes in other variables in their research. So, it can be concluded that it is clear that the research to be carried out is to prove the existence of influence and cause and effect. Therefore, researchers in this study attempted to prove whether Servant Leadership (independent variable X1) can affect Organizational Commitment (dependent variable Y) through Workplace Spirituality (intervening variable Z1) and Work Motivation (intervening variable $\mathrm{Z2}$ ) in the millennial generation within Tangerang area. In this study, primary data will be collected in relation with the variables of Work Motivation, Workplace Spirituality, Servant Leadership, and Organizational Commitment using survey research, with the tool used in form of a set of questionnaires in which the data obtained is the scores on each answer from the respondents, written and recorded, then the data will be quantified in the form of numbers obtained from the measurement results of the questionnaires. In general, the scoring used in this research questionnaire is rated by using Likert scale. Based on the hypothesis that has been made by the researchers, the variables of this study are Servant Leadership (X1) as an Independent variable (free variable) and Organizational Commitment (Y) as 
the dependent variable (bound variable) While Work Spirituality (Z1) and Work Motivation (Z2) play their roles as intervening variables.

\section{RESULTS AND DISCUSSION}

Path analysis is applied in this study to determine the effect of a direct relationship between servant leadership and workplace spirituality; a direct relationship between servant leadership and work motivation; a direct relationship between servant leadership, workplace spirituality, and work motivation on organizational commitment; and an indirect relationship between servant leadership towards organizational commitment through workplace spirituality and work motivation. Where this test is carried out through the calculation of a 3-stage regression equation: stage 1 testing the effect of servant leadership on workplace spirituality; stage 2 testing the effect of servant leadership on work motivation; and stage 3 testing the effect of servant leadership, workplace spirituality and work motivation on organizational commitment.

\section{Hypotheses Testing}

Hypothesis testings were conducted to determine direct and indirect effects between variables. The results of the decisions on all the proposed hypotheses are described as follows:

\section{The Effect of Servant Leadership on Workplace Spirituality}

At this stage, the first hypothesis testing, which sees the effect of servant leadership on workplace spirituality, results from the calculation of the dependent variable measured by servant leadership which has a positive coefficient which means that servant leadership has a positive relationship with workplace spirituality of 0.591 . Furthermore, the data management stage uses a significance of 0.05 . The servant leadership variable for workplace spirituality was obtained a significance value of 0.000 , where sig $<0.05$ which means that servant leadership has a positive and significant effect on workplace spirituality.

\section{The Effect of Servant Leadership on Work Motivation}

In the second hypothesis testing stage, which sees the effect of servant leadership on work motivation, the results of the calculation of the dependent variable as measured by servant leadership have a positive coefficient which means that servant leadership has a positive relationship with work motivation value of 0.49. Furthermore, the data management stage uses a significance of 0.05 . In the servant leadership variable on work motivation, a significance value of 0.000 is obtained where sig $<0.05$, which means that servant leadership has a positive and significant effect on work motivation.

\section{The Effect of Servant Leadership on Organizational Commitment}

In the third hypothesis testing stage, which sees the effect of servant leadership on organizational commitment, the results of the calculation of the dependent variable as measured by the servant leadership variable have a positive coefficient value of 0.075 . Furthermore, the data management stage uses an error rate of 0.05 . In the servant leadership variable on organizational commitment, a significance value of 0.292 is obtained where sig $>0.05$, which means that servant leadership does not have a positive and significant effect on organizational commitment.

\section{The Effect of Workplace Spirituality on Organizational Commitment}

At the fourth hypothesis testing stage, which saw the effect of workplace spirituality on organizational commitment, the results of the calculation of the dependent variable measured by the workplace spirituality variable had a positive signalling efficiency value which meant that workplace spirituality had a positive relationship with the organizational commitment of 0.451. Furthermore, the data management stage uses an error rate of 0.05 . In the variable on organizational commitment, a significance value of 0.000 is obtained where sig $<0.05$, which means that workplace spirituality has a positive and significant effect on organizational commitment.

\section{The Effect of Work Motivation on Organizational Commitment}

In the fifth hypothesis testing stage, which saw the effect of work motivation on organizational commitment, the results obtained from the calculation of the dependent variable as measured by the work motivation variable which has a positive efficiency value, which means that work motivation has a positive relationship with the organizational commitment of 0.286 . Furthermore, the data management stage uses an error rate of 0.05 . In the variable on organizational commitment, a significance value of 0.000 is obtained where sig $<0.05$, which means that work motivation has a positive and significant effect on organizational commitment.

\section{The Effect of Servant Leadership on Organizational Commitment through Workplace Spirituality}

Based on the model findings that the researchers have explained, which sees the effect of servant leadership indirectly on organizational commitment through workplace spirituality. The results obtained from the calculation of the dependent variable as measured by organizational commitment have a positive coefficient value of 0.341 with the results of the total effect of servant leadership on organizational commitment through workplace spirituality, namely $0.075+(0.591 \times 0.451)$. Furthermore, the data management stage uses an error rate of 0.05. In the variable on organizational commitment, a significance value of 0.000 is obtained where sig $<0.05$, which means that servant leadership has a positive and significant effect on organizational commitment through workplace spirituality.

\section{The Effect of Servant Leadership on Organizational Commitment through Work Motivation}

Based on the findings model that the researchers has explained to see the effect of servant leadership on organizational commitment through work motivation. Obtained from the calculation of the dependent variable as measured by 
organizational commitment which has a positive coefficient value of 0.140 with the results of the total effect of servant leadership on the organizational committees through work motivation is $0.075+(0.49 \times 0.286)$. Furthermore, the data management stage uses an error rate of 0.05 . In the variable on organizational commitment, a significance value of 0.000 is obtained where sig $<0.05$, which means that servant leadership has a positive and significant effect on organizational commitment through work motivation. The following is a table of the results of calculating the overall effect based on the calculations that have been done previously:

[Table 1 about here.]

This section will present a hypothesis testing analysis in which to see the direct and indirect effects of the independent variable and the dependent variable. This study tested Hypothesis 1, Hypothesis 2, Hypothesis 3, Hypothesis 4, Hypothesis 5, Hypothesis 6, and Hypothesis 7 which are the hypotheses of this study. Table 5.1 shows a summary of the results of hypotheses testing which will be described below:

[Table 2 about here.]

\section{The Effect of Servant Leadership on Workplace Spirituality}

Based on the results of the data testing in this study, the first hypothesis shows that servant leadership has a positive and significant effect on workplace spirituality. The higher the servant leadership attitude of a manager, the more workplace spirituality that millennial generation employees have. Most of the respondents in this study were around 20-26 years old, where they tended to feel that support and relationships with managers were very influential with the work environment in order to create comfortable conditions. The attitude of managers who pay attention to their subordinates is very accepted by the millennial generation because they really need a good relationship with managers in accordance with millennial characteristics who want to build relationships not only with colleagues but with superiors. The support provided by managers can make employees feel not only as workers but as members of a family in an organization. Based on this, dealing with servant leadership variable, there is a statement that has the highest value that the respondent agrees with, namely the manager gives a good attitude to his employees, this shows that the millennial generation really wants good relationships and support from their managers. In order to create good relationships, managers can guide, assist, and care for their subordinates.

\section{The Effect of Servant Leadership on Organizational Commitment}

Based on the results of the data testing in this study, the second hypothesis shows that servant leadership does not have a positive and significant effect on organizational commitment. This can be indicated that there are still leaders who play their roles as dictators or do not pay attention to their subordinates so that the level of commitment of the millennial generation in the organization decreases. By paying attention to the characteristics of millennials, i.e. they do not like being bound to regulations so that such dictatorship leaders' trait is not suitable for millennial generation's employees.

\section{The Effect of Servant Leadership on Work Motivation}

Based on the results of testing this research data, the third hypothesis shows that servant leadership has a positive and significant effect on work motivation. It can be indicated that the higher the servant leadership, the higher the work motivation. Most of the respondents in this study were aged 2026 years, where the millennial generation at that age has a high enough enthusiasm for work so that with the support of servant leadership it can increase millennial motivation to work. With this support, it is able to foster productivity and the effectiveness of millennial generation employee performance in achieving the desired targets. The statement that has the highest value is approved by the respondent, i.e. the manager gives a good attitude to employees because the millennial generation who gets good behaviour from the manager can foster initiative, motivate employees to work even better, and cause a desire to increase the ability to be better and gain achievements in the organization.

\section{The Effect of Workplace Spirituality on Organizational Commitment}

Based on the results of testing the data of this study, the fourth hypothesis shows that workplace spirituality has a positive and significant effect on organizational commitment. This can be indicated that the higher the workplace spirituality in the work environment, the higher the employee's organizational commitment. Most of the respondents in this study had worked for more than one year, which means that the millennial generation was able to increase commitment within the organization because of the support from workplace spirituality. The statement that has the highest value approved by respondents in workplace spirituality is that I feel happy if I reach the target given which is included in the dimension of alignment with organization value, which means that the millennial generation is able to contribute well to the company because they deserve to do this and the atmosphere of the organization environment is so good that it is able to foster the desire of the millennial generation to remain in the organization.

\section{The Effect of Work Motivation on Organizational Commitment}

Based on the results of testing the data of this study, the fifth hypothesis shows that work motivation has a positive and significant effect on organizational commitment. This means that the higher the employee's work motivation, the higher the level of employee commitment in an organization. Most of the 
respondents in this study had worked at the company for more than one year. Based on the characteristics of the millennial generation, they have a high interest in something because they want to get a lot of things in the organization so that this desire can trigger employee commitment. The statement that has the highest value agreed by the respondents on work motivation is that the millennial generation gets a lot of information from people in the work environment, which means that they feel happy when they get information in the work environment because they feel the information obtained is very useful both in their work environment or outside their work environment. This is in accordance with employees who have worked for more than one year where there is a lot of information that they can collect within their work environment.

\section{The Effect of Servant Leadership on Organizational Commitment through Workplace Spirituality}

Based on the results of testing the data in this study, the sixth hypothesis proves that servant leadership has a positive and significant effect on organizational commitment through workplace spirituality with a greater value than the effect of servant leadership on direct organizational commitment. This means that servant leadership has a greater effect on organizational commitment when going through workplace spirituality. This can be indicated that workplace spirituality can be an intervening variable for spiritual leadership on organizational commitment. It can be concluded that the existence of a workplace spirituality that supports servant leadership in organizations can increase the commitment of the millennial generation. Workplace spirituality has a role in providing comfort and the assumption that millennial generation employees are very valuable in the company. According to the respondents, most of whom are 20-26 years old, who have worked for more than one year for the companies, they will be very supportive in increasing the work commitment of millennial generation employees.

\section{The Effect of Servant Leadership on Organizational Commitment through Work Motivation}

Based on the results of testing the data in this study, the sixth hypothesis proves that servant leadership has a positive and significant effect on organizational commitment through work motivation with a value greater than the effect of servant leadership on direct organizational commitment. This means that servant leadership has a greater effect on organizational commitment through work motivation. This can be indicated that work motivation can be an intervening variable for servant leadership to organizational commitment. It can be concluded that the existence of employee work motivation that supports servant leadership in the organization can increase the organizational commitment of the millennial generation. Work motivation plays a role in describing the characteristics of the millennial generation who have a high willingness at the workplace and want to get new experiences at work. According to the respondents, most of whom are aged 20-26 years who have worked for more than one year, they will be very supportive in increasing the work commitment of millennial employees.
This study aims to determine the effect of servant leadership on organizational commitment through workplace spirituality and servant leadership in the millennial generation. Based on the findings of the research and the results of the analysis that has been carried out, the following conclusions are drawn:

Servant leadership does not have a significant and positive influence on organizational commitment, meaning that there are still leaders who have not given good attitudes to their subordinates, causing a decrease in the commitment of millennial generation workers in the organization. Servant leadership has a significant and positive effect on workplace spirituality. It can be interpreted that a good leader's attitude is able to provide a positive atmosphere at work. Servant leadership has a significant and positive effect on work motivation. Because leaders will really pay attention to their subordinates if they show a high willingness to work so that they can increase the ability of the millennial generation to work as well as to foster a good relationship between leaders which will be able to.

Workplace spirituality has a significant and positive influence on organizational commitment. Because with the creation of a good work environment will give the millennials the opportunity to take part in work and at the same time it can also increase their commitment in an organization by being given the opportunity they meed. Millenials will feel that they are being recognized both for expertise and figures in the organization.

Work motivation has a significant and positive influence on organizational commitment, meaning that millennial generation employees who have the desire to work in the organization and the desire to gain valuable things in the form of work experience, work relationships, and information can foster better commitment within the organization.

Servant leadership has a positive and significant effect on organizational commitment through workplace spirituality. This means that workplace spirituality is proven as an intervening variable for servant leadership on organizational commitment. This means that if the leader in the organization has a good attitude towards his subordinates, it can create a positive work environment so that the millennial generation employees have a commitment to the organization. Servant leadership has a positive and significant effect on organizational commitment through work motivation. This means that work motivation is proven to be an intervening variable for servant leadership towards organizational commitment. This means that if the leader in the organization provides a good attitude, it can increase the desire to work for millennial generation employees so that commitment in the organization can be created. Based on the conclusions obtained in this study, the authors propose the following suggestions as a complement to this research: Millennial generation needs to have work motivation because it has a considerable influence on organizational commitment, this is because of the nature of the millennial generation who has a very high curiosity in learning about new things so that it can increase commitment within the organization. When there is a match between the work motivation and organizational commitment of the millennials, it is hoped that those millennials can increase their work productivity. Besides, millennials' work motivation can be boosted as well because of the characteristics 
of the millennials who always want to try new things and it can be a factor in increasing the performance of the millennials. Workplace spirituality needs to be held in every organization because it has a considerable influence on organizational commitment. With workplace spirituality, the millennials feel that they are involved in the organization and become a part of the organization. This causes the millennials to make innovations and initiatives at work.

Servant leadership needs to be possessed by every manager because it can trigger a considerable amount of influence on commitment in the organization. Managers who pay attention to their followers well will get excellent feedback such as a productive performance and a good relationship so that in doing the work the millennials will do very well and on their own accord without feeling coercion from other parties. For further research, try to implement other variables besides work motivation, such as Personality Traits, because it is estimated that the use of such variable will bring a better effect, where the previous variables being tested are closely related to the characteristics of the millennials. For further research, it can be done by paying attention to the phenomena related to the reduction of the impact of the Covid-19 pandemic because the research on the effect of human resources on the postpandemic settings will be very suggestible.

\section{CONCLUSION}

There are still leaders who have not given good attitudes to their subordinates, causing a decrease in the commitment of millennial generation workers in the organization. The attitude of a good leader can provide a positive atmosphere in the workplace. Leaders will really pay attention to their subordinates if they show a high willingness to work so that they can increase the ability of the millennial generation to work as well as the good relationships that the leaders have. By creating a good work environment, giving the millennial generation the opportunity to take part in work can increase commitment in an organization by being given this opportunity they feel that the millennial generation is recognized both for their expertise and figures in the organization. Millennial generation employees who have a desire to work within the organization, the desire to gain valuable things in the form of work experience, work relations and information can foster commitment within the organization. Workplace spirituality is proven as an intervening variable for servant leadership towards organizational commitment. This means that if the leader in the organization has a good attitude towards his subordinates, it can create a positive work environment so that the millennial generation employees have a commitment to the organization. Work motivation is proven as an intervening variable for servant leadership towards organizational commitment. This means that if the leader in the organization gives a good attitude, it can increase the desire to work for millennial generation employees so that commitment in the organization can be created.

\section{AKNOWLEDGEMENT}

The new research model found in this study is that the indirect effect on organizational commitment in this study is greater, namely servat leadership on organizational commitment through workplace spirituality compared to the effect of direct servant leadership on organizational commitment. This means that the millennial generation at work not only wants leaders who support and help their subordinates but the millennial generation also pays attention to factors in the work environment to be able to create high organizational commitment.

The second new research model found in this study is that the indirect effect on organizational commitment in this study is greater, namely servant leadership on organizational commitment through work motivation, compared to the effect of direct servant leadership on organizational commitment. From the results obtained indirectly, it means that the work commitment of the millennial generation is more influential if it is through work motivation. This can mean that in working the millennial generation needs to pay attention to the work motivation factor, because if there is no desire to work, there will be no commitment in an organization even though the leader is good, so there needs to be work motivation in the millennial generation 


\section{REFERENCES}

Adiputra, E. (2015). Perilaku Pembelian Tidak Terencana (Impulse Buying) Di Pusat Perbenjaan Modern Di Surabaya. AnNisbah: Jurnal Ekonomi Syariah, Vol.01(No.02), 155-180. https://doi.org/10.21274/an.2015.1.2.155-180

Artana, I. P. W., Wisesa, I. G. B. S., Setiawan, I. K., Utami, N. L. P. M. P., Yasa, N. N. K., \& Jatra, M. (2019). Pengaruh store Atmosphere, Display poduct, dan pice Discount terhadap Impulse Buying. E-Jurnal Ekonomi Dan Bisnis Universitas Udayana, Vol.8(No.4), 369-394.

Deviana D, N. P. S., \& Kt.Giantari, I. G. A. (2016). Pengaruh Shopping Lifestyle Dan Fashion Involvement Terhadap Impulse Buying Behaviour Masyarakat Di Kota Denpasar. E-Jurnal Manajemen Universitas Udayana, Vol.5(No.8), 5264-5273.

Fauziyyah, A. N., \& Oktafani, F. (2018). Pengaruh Shopping Lifestyle Dan Fashion Involvement Terhadap Impulse Buying Behavior (Studi pada Masyarakat Kota Bandung). JURISMA: Jurnal Riset Bisnis \& Manajemen, Vol.8(No.1), 1-14. https://doi.org/10.34010/jurisma.v8i1.994

Febriani, S. F., \& Purwanto, N. (2019). Pengaruh Shopping Lifestyle Dan Fashion Involvement Terhadap Impulse Buying Pada Konsumen Hijab Butik Rabbani Jombang. JMD: Jurnal Riset Manajemen \& Bisnis Dewantara, Vol.2(No.2), 53-62. https://doi.org/10.26533/jmd.v2i2.372

Gunawan, G. T., \& Sitinjak, T. (2018). Pengaruh Keterlibatan Fashion Dan Gaya Hidup Berbelanja Terhadap Pembelian Impulsif (Studi Terhadap Remaja Dan Pemuda Dki Jakarta). Jurnal Manajemen, Vol.7(No.2), 109-123.

Haironi, M. (2018). Pengaruh Discount, Bonus Pack, Dan In-Store Display Terhadap Impulse Buying Produk Obat Nyamuk HIT di Pamella Swalayan Yogyakarta. Journal Ekobis Dewantara, 1(3), 118-126.

Irawan, D. O., Arifin, R., \& Basalamah, M. R. (2020). Pengaruh Shopping Lifestyle, Discount, Fashion Involvement, Hedonic Shopping Motivation, dan Promosi Penjualan Terhadap Impulse buying (Studi Kasus Pada Mahasiswi Yang Pernah Berkunjung Ke Center Point Di Mall Olympic Garden Malang). E-Jurnal Riset Manajemen Prodi Manajemen Fakultas Ekonomi Dan Bisnis Unisma, Vol.09(No.04), 152-167.

Melina, \& Kadafi, M. A. (2017). Pengaruh price discount dan in-store display terhadap impulse buying. Forum Ekonomi, Vol.19(No.2), 201-209. http://journal.feb.unmul.ac.id/index.php/FORUMEKONOMI

Pontoh, M. E., Moniharapon, S., \& Roring, F. (2017). Pengaruh Display Produk dan Store Atmosphere Terhadap Impulse Bulying pada Konsumen Matahari department Store Mega Mall Manado. Jurnal Emba, Vol.5(No.2), 1823-1833. https://doi.org/10.1063/1.4740043

Priyatno, D. (2018). SPSS Panduan Mudah Olah Data Bagi Mahasiswa \& Umum. Penerbit ANDI.

Sari, D. K. (2018). Peran In Store Stimuli Dalam Customer Impulse Buying Serta Implikasinya Terhadap Strategi Pemasaran Pada Minimarket. Eksis: Jurnal Riset Ekonomi Dan Bisnis, Vol.13(No.2), 101-110.

Sonata, I. (2019). Pengaruh Price Discount Dan Store Atmosphere Terhadap Keputusan Impulse Buying Pada. Jurnal Riset Manajemen \& Bisnis (JRMB), Vol.4(No.1), 46-53.

Sugiyono. (2017). Metode Penelitian Kuantitatif, Kualitatif, dan R\&D. Alfabeta.

Sumarwan, U. (2015). Perilaku Konsumen Teori dan Penerapannyadalam Pemasaran.

Supranto, J. (2016). Statistik Teori \& Aplikasi (8(2)). Penerbit Erlangga.

Tjiptono, F. (2015). Strategi Pemasaran (Edisi 4). Penerbit ANDI.

Utami, C. W. (2017). Manajemen Ritel Strategi dan Implementasi Operasional Bisnis Ritel Modern di Indonesia (Edisi 3). Salemba Empat.

Widiyati, S., \& Ghozi, S. (2018). Peningkatan Impulse Buying Mahasiswa di Semarang terhadap Produk Fashion Lokal melalui Ethnocentrisme, Brand Image dan Country of Origin (COO). Esensi: Jurnal Bisnis Dan Manajemen, Vol.8(No.1), 4956. https://doi.org/10.15408/ess.v8i1.6979

Wilujeng, S. (2017). Pengaruh Price Discount Dan Bonus Pack Terhadap Impulse Buying Konsumen Indomaret di Kecamatan Sukun Kota Malang. Journal FEB Universitas Kanjuruhan Malang, 457-469.

Zayusman, F., \& Septrizola, W. (2019). Pengaruh Hedonic Shopping Value dan Shopping Lifestyle Terhadap Impulse Buying pada Pelaggan Tokopedia di Kota Padang. Jurnal Kajian Manajemen Dan Wirausaha, Vol.01(No.01), 360-368.

Conflict of InterestStatement:The authorsdeclare that theresearch was conducted in the absence of any commercial or financial relationships that could be construed as a potential conflict of interest.

Copyright $($ tahun terbit nama belakang and nama belakang. This is an open-access article distributed under the terms of the Creative Commons Attribution License (CC $B Y)$. The use, distribution or reproduction in other forums is permitted, provided the original author(s) and the copyright owner(s) are credited and that the original publication in this journal is cited, in accordance with accepted academic practice. No use, distribution or reproduction is permitted which does not comply with these terms. 


\section{LIST OF FIGURES}

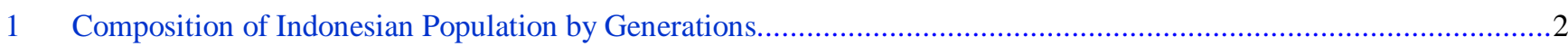

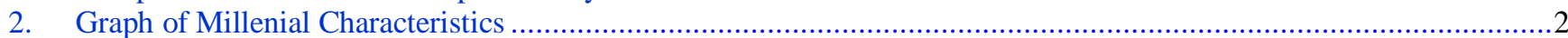


Komposisi Penduduk Menurut Generasi (persen), 2017

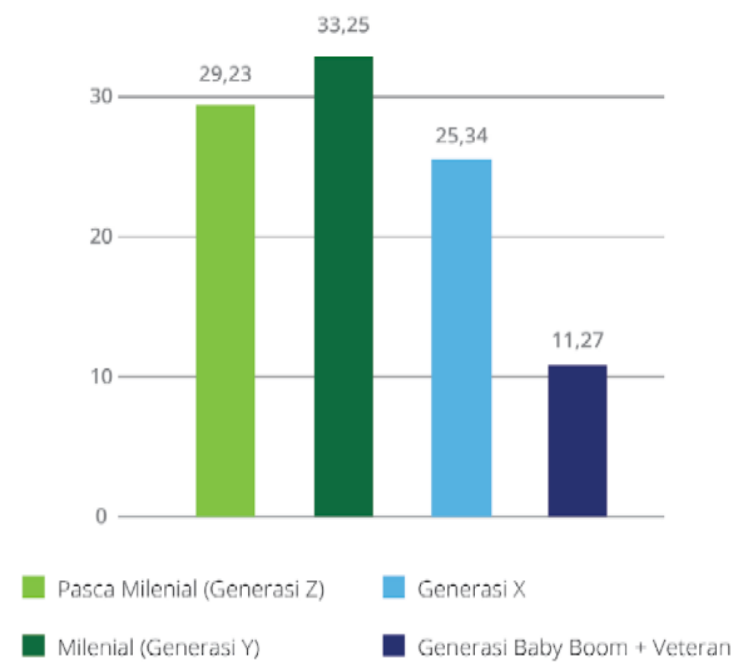

Figure 1 | Composition of Indonesian Population by Generations

Source: Deloitte Indonesia Perspectives, 2019

Note:

Pasca Milenial $($ Generasi Z $)=29.23$

Milenial (Generasi Y) $=33,25$

Generasi $\mathrm{X}=25,34$

Generasi Baby Boom + Veteran $=11,27$
Post Millennial $($ Generation Z $)=29.23$

Millennial (Generation Y) $=33.25$

Generation $\mathrm{X}=25.34$

Baby Boomers + Veterans $=11.27$ 


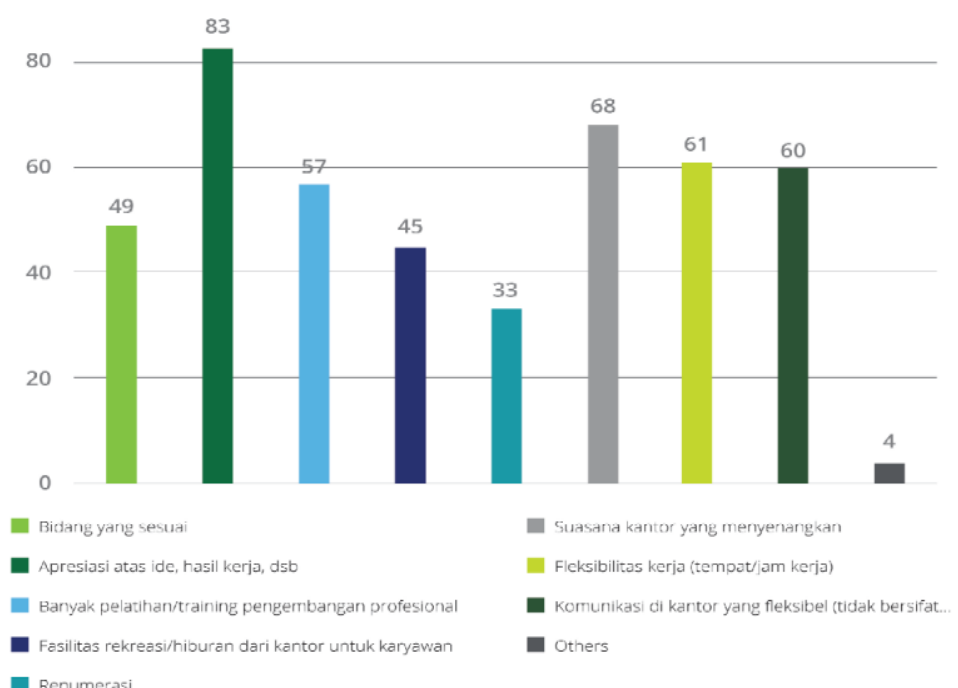

Figure 2 | Graph of Millenial Characteristics

Note:

Bidang yang sesuai $=49$

Apresiasi atas ide, hasil kerja, dsb $=83$

Banyak pelatihan / training pengembangan professional $=57$

Fasilitas rekreasi/hiburan dari kantor untuk karyawan $=45$

Renumerasi $=33$

Suasana kantor yang menyenangkan $=68$

Fleksibilitas kerja (tempat/jam kerja) $=61$

Komunikasi di kantor yang fleksibel (tidak bersifat...) $=60$

Lain-lain $=4$
Suitable field $=49$

Appreciation of ideas, work, etc. $=83$

Lots of professional development

workshops/trainings $=57$

Recreational/entertainment facilities from office for employees $=45$

Remuneration $=33$

Nice office atmosphere $=68$

Work flexibility (place/working hours) $=61$

Flexible office communication (not discussing about...) $=60$

Others $=4$ 


\section{LIST OF TABLES}

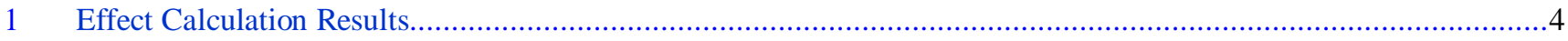

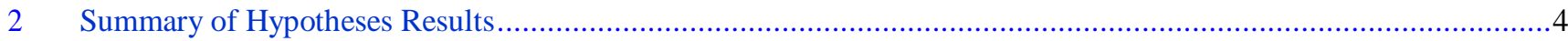


TABLE 1 / Effect Calculation Results

TABLE 1| Effect Calculation Results

\begin{tabular}{lcccc}
\hline \multicolumn{1}{c}{ Variable } & Path Coefficient & Direct & Effect \\
$\mathrm{Indirect}$ & Total \\
$\mathrm{X} \rightarrow \mathrm{Z} 1$ & 0.591 & - & - & 0.591 \\
$\mathrm{X} \rightarrow \mathrm{Z} 2$ & 0.490 & - & - & 0.490 \\
$\mathrm{X} \rightarrow \mathrm{Y}$ & - & - & - & - \\
$\mathrm{Z} 1 \rightarrow \mathrm{Y}$ & 0.451 & - & - & 0.451 \\
$\mathrm{Z} 2 \rightarrow \mathrm{Y}$ & 0.286 & - & - & 0.286 \\
$\mathrm{X} \rightarrow \mathrm{Z} 1 \rightarrow \mathrm{Y}$ & - & 0.075 & 0.266 & 0.341 \\
$\mathrm{X} \rightarrow \mathrm{Z} 2 \rightarrow \mathrm{Y}$ & - & 0.075 & 0.14 & 0.215 \\
\hline \multicolumn{5}{r}{ Source: Data processed (2020) }
\end{tabular}


TABLE 2 / Summary of Hypotheses Results

TABLE 2|Summary of Hypotheses Results

No

\section{Hypothesis}

1. H1: It is suspected that there is an influence of Servant Leadership on Workplace Spirituality

2. H2: It is suspected that there is an influence of Servant Leadership on Organizational Commitment

3. H3: It is suspected that there is an influence of Servant Leadership on Work Motivation

4. H4: It is suspected that there is an influence of Workplace Spirituality on Organizational Commitment

5. H5: It is suspected that there is an influence of Work Motivation on Organizational Commitment

6. H6: It is suspected that there is an influence of Servant Leadership on Organizational Commitment through

6. Workplace Spirituality

7. H7: It is suspected that there is an influence of Servant Leadership on Organizational Commitment through Work Motivation

Source: Data processed (2020)

Result

Approved

Rejected

Approved

Approved

Approved

Approved

Approved 
